\title{
Tourist perceptions and uses of urban green infrastructure: an exploratory cross-cultural investigation
}

Terkenli, T. S. ${ }^{1}$; Bell, S. ${ }^{2}$; Toskovic, O. ${ }^{3}$; Tomicevic-Dubljevic, J. ${ }^{4}$; Panagopoulos, T. ${ }^{5}$; Straupe, I. ${ }^{6}$; Kristianova, K. ${ }^{7}$; Straigyte, L. ${ }^{8}$; O’Brien, L. ${ }^{9}$; Zivojinovic, I. ${ }^{10^{*}}$

${ }^{1}$ Department of Geography, University of the Aegean, Mytilini, Greece, t.terkenli@aegean.gr

${ }^{2}$ Department of Landscape Architecture, Estonian University of Life Sciences, Tartu, Estonia

${ }^{3}$ Laboratory for Experimental Psychology, Faculty of Philosophy, University of Belgrade, Serbia

${ }^{4}$ Department of Landscape Architecture and Horticulture, University of Belgrade, Faculty of Forestry, Serbia

${ }^{5}$ Research Centre for Tourism, Sustainability and Well-being, University of Algarve, Faro, Portugal

${ }^{6}$ Forest Faculty, Latvia University of Life Sciences and Technologies, Jelgava, Latvia

${ }^{7}$ Faculty of Architecture, Slovak University of Technology in Bratislava, Bratislava, Slovakia

${ }^{8}$ Faculty of forest Sciences and Ecology, Aleksandras Stulginskis University, Kaunas, Lithuania

${ }^{9}$ Centre for Ecosystems, Society and Biosecurity, Social and Economic Research Group (Forest

Research), Surrey, United Kingdom

${ }^{10^{*}}$ Institute of Forest, Environment and Natural Resource Policy, University of Natural Resources and Life Sciences, Vienna (BOKU) and European Forest Institute, Forest Policy Research Network Feistmantelstrasse 4, A-1180 Vienna, Austria, ivana.zivojinovic@boku.ac.at (corresponding author)

\section{Abstract}

Urban Green Infrastructure (UGI) serves both inhabitants' and visitors' numerous and various needs. This research aimed to enhance knowledge regarding the role of UGI in urban tourism. The research questions addressed tourists' perceptions of UGI, their understanding and uses of UGI, and the ways that this understanding influenced their travel choice to specific urban destinations. A cross-cultural comparative study among urban tourists was carried out in eight European countries. The selection of case studies followed a roughly comparative logic, employing the same on-site questionnaire survey administered in a sample of large and medium size cities in Southern European, Central European and Northern European countries. Looking from the perspective of the tourists' countries of origin, our findings validate a well-established trend in international tourism, namely the fact that neighbouring countries tend to be the most significant tourist markets of an urban destination. The 
other major finding confirmed the most well-known tourist movement patterns of Northern and Central Europeans travelling to the Mediterranean for tourism purposes. While the study revealed that the majority of the tourists interviewed were not very familiar with the term 'Green Infrastructure', nor with specific UGI features offered in the visited cities, the importance of UGI was acknowledged and viewed in a mostly very positive light. The majority of respondents enjoyed visiting UGI and used it for some light physical activity or for purposes of relaxation, socialization, and in order to explore the culture and society of the destination city. The fact that most UGI in the case study cities is located around or within a short distance from important heritage sites provided UGI with an indirect possibility of being included in the tourists' visiting plans. In conclusion, the results of this study may prove to be very helpful to local and regional authorities in considering how to plan, manage and promote an urban tourism destination's green infrastructure as part of the tourism offer.

Key words: green spaces, urban forest, European city, tourist destination, urban green tourism, green city branding

\section{Introduction}

The concept of "urban green infrastructure" (UGI) has emerged in the last few decades as a model for considering all forms of green spaces as an integrated network and of an importance equivalent to other urban infrastructure such as roads or energy systems. Its use has been gaining popularity in planning theory and policy, despite the difficulty in achieving a single definition. Here we refer to strategically planned networks of high quality designed, natural and semi-natural areas, including also other environmental features such as waterbodies, planned and managed to deliver a wide range of ecosystem services to their users and to protect biodiversity in urban settings (Jankovska et al, 2010; Berte and Panagopoulos, 2014). Practically speaking, UGI principally consists of urban parks, gardens, woodlands, nature areas, green streets and avenues and so on (Parker and Zingoni de Baro 2019), as discussed in more detail below.

Current demographic trends indicate population growth in most urban areas worldwide, many becoming home to culturally diverse groups (in terms of race and ethnicity, traditions etc.) (Sasidharan et al., 2005). Much scientific literature already exists on the uses of and values placed on UGI by local residents and, generally speaking, recreational users, in urban settings, around Europe, including the use of urban green areas by various racial and ethnic minority groups (Mell 2017; Sasidharan et al, 2005). However, urban tourism is a growing trend, especially in the "off-season", with short breaks becoming popular all-year round in part as a result of cheaper airline travel but 
also for events and other activities marketed through effective branding and promotion. In research focusing on city branding there is some which focuses primarily on the use of green resources in the place branding context (Chan and Marafa, 2014; Gulsrud et al., 2013; Simon, 2004) but it is limited. However, the uses of UGI by these tourists and their corresponding perceptions have not yet been researched to any degree, nor does do available studies attempt to do so cross-culturally. Most relevant research on UGI use by visitors refers to selected European cases, which only represent certain types of UGI offered for urban tourism.

It is now clear that urban parks do not only provide recreational settings to local residents. Visitors from out-of-town will also use these green spaces as part of the suite of sights they plan to visit on their itineraries or as incidental locations, perhaps for shade in hot sunny weather or to escape the crowds. In some cases, particularly high-profile parks are major tourist attractions in their own right, such as the Central Park and the High-Line in New York City, (Konijnendijk et al., 2013). Hyde Park in London, Parc Güell in Barcelona - where tickets now have to be bought in advance, such is the demand and risk of crowding - and many others can also be considered destination parks (Terkenli et al., 2017). UGI may add value to urban tourism, or it may constitute the main tourist lure, e.g. the city of Minneapolis in the USA may be considered as a UGI urban tourist destination. Understanding the role of UGI in tourism and the values it offers to the tourism experience has potential benefits to the cities concerned both in a tourism promotion and tourism management context.

While tourists plan and carry out their visits to cities in a number of ways, the role and significance of UGI in the tourist experience acquires variable forms and weights according to the tourism product offered, in smaller versus larger urban destinations. Bigger cities tend to offer a greater variety of UGI possibilities, by nature of their size and the range of recreational possibilities, as opposed to smaller urban centres (cities and towns), usually connected to special-interest or alternative forms of tourism. In the latter, urban tourism tends to be variably, but also selectively related to the use of UGI and often in very specific ways, in connection to the form of tourism attracting visitors there in the first place. Whether intended or not, some UGI uses in European tourist destination cities are integral to the tourist visit, as noted above, while other UGI usage tends to be more or less incidental to the overall tourism experience (for instance, UGI may play a much more central role in small urban wellness and thermal destinations, or cultural landscape heritage sites (eg. Lednice-Valtice or Kromeriz near Brno in the Czech Republic), or even in pilgrimage destinations (eg. Fatima in Portugal, Wiltshier, 2009), rather than in destinations strictly connected with cultural and nightlife attractions (eg. Riga, Latvia and Bratislava, Slovakia). 


\section{Research gap, aims and questions}

Therefore, a gap exists in the understanding of how UGI uses are connected and relate to various forms of tourism and the supply-side of tourism (conventional, special-interest, alternative, etc.) (Tyrväinen et al., 2007; Madureira et al., 2015), as well as the demand/market side of tourism (tourist provenance/residence). This study therefore aims to start to address this research gap, by offering a first insight into trends of tourist use and perception of UGI in a limited sample of European cities, from both the supply and demand side of tourism. In this way it also contributes to the larger body of urban tourism literature which identified the lack of insights on how tourists actually use cities (Ashworth and Page, 2011).

Specifically, this research aims to enhance knowledge about the role of UGI in urban tourism, by addressing tourists' perceptions of UGI, their understanding and uses of UGI, and the ways that this understanding influences their travel choice to specific urban destinations. It is carried out through a cross-cultural comparative study among urban tourists carried out in eight European countries. It aims to explore significant aspects and dimensions of the complex, multi-layered and often spontaneous relationships that emerge out of tourists' contact and deployment of UGI, in the course of their visits to destination cities. This includes perceptions, understandings, preferences and emotions linked to the tourists' experience of UGI and correlated with their country of residence.

We addressed the following research questions:

1. How do urban tourists perceive and understand UGI, in the context of their overall tourism experience?

2. How do urban tourists tend to use UGI, in the context of their overall tourism experience?

3. How do these tourist perceptions and uses differ cross-culturally?

4. How do these tourist perceptions and uses differ in terms of their destination country/region?

\section{Urban green infrastructure, its values and uses}

\section{The benefits of UGI}

As briefly noted above, UGI consists of forests, parks, green corridors, roadside alleés, gardens, cemeteries and various sorts of open public spaces, all of which represent urban amenities through space and time (Parker and Zingoni de Baro, 2019). In European cities, the inclusion and maintenance of green areas has a long tradition since the development of human civilization 
(Cekule, 2010). After the industrial revolution and the wave of urbanization which followed in the $19^{\text {th }}$ century, urban green-space recreation became a major element of European bourgeois culture (Tyrväinen et al., 2005). With further urbanization and a growing demand for and pressures on urban green areas during the $20^{\text {th }}$ century, green space planning and management became an established municipal role (Konijnendijk and Randrup, 2004). The functions of UGI differ widely across Europe due to different environmental and socio-cultural contexts (Andrada and Deng, 2010) with different types prevailing in different regions.

As an example of these difference we can look at urban forests. The forest cultures of northern Europe, in the Baltic countries and Fennoscandia are rather similar, in that the forest is a significant element of everyday life, is important in national economies, and is a major element of the landscape (Matileinen et al, 2019; Tyrväinen et al., 2006; Bell, 2008). In this respect, the recreational and aesthetic benefits of urban forests - into which the urban areas have encroached over time - are also traditionally important in this region (Gunnarsson and Øhrstroom, 2007, Chen and Jim, 2008). This is different from central Europe, where land conversion processes have been profound. In Latvia as in other countries of North Europe, the human footprint on nature throughout the twentieth century and the alienation between people and nature had less impact than in other European cases (Jankovska et al., 2014). These findings also extend to (urban) forest ownership (Matilainen et al., 2019).

The benefits of UGI to its users has been studied through many European and North American case studies (O'Brien et al., 2017). These all demonstrate how UGI has the potential to improve significantly the quality of the urban environment and the well-being of its residents. Reduced stress and improved physical health for urban residents have been associated with the presence of urban trees and forests (Carrus, 2017; Vujcic and Tomicevic, 2018; Vujcic et al., 2019). Urban forests also possess high educational values by representing nature and natural processes in cities and towns. Urban parks, green corridors, greenways, and open green spaces are also of strategic importance for the quality of life of our increasingly urbanized society (Chiesura, 2004; Galečić et al., 2016); there is general agreement that they are essential for liveable and sustainable cities and towns (Konijnendijk et al., 2013). Planners and managers have, however, underestimated the potential benefits that UGI can provide and have not grasped the culturally-dependent roles, processes and means needed to provide those benefits, particularly the linkages between benefits and characteristics of UGI and its management (Dwyer et al., 1992; Gudurić et al., 2011). 
Monitoring and analysis of the flow of visitors to natural recreational areas is one of the indicators of the social functioning of forests and nature areas (Jankovska et al., 2013), but we need to explore further the ways in which visitors perceive, connect to and use UGI. It is important to assess people's beliefs about the functions of urban green spaces, as people's opinions may generate conflicts between residents, planners and managers (Eriksson et al., 2012; Madureira et al., 2015). In addition, assessing various perceptions of stakeholders toward the use of UGI is important, since they sometimes have different objectives for the use of these areas (Gudurić et al., 2011; Živojinović and Wolfslehner, 2015). This two-directional understanding of UGI can improve urban planning, vegetation management, urban sustainability, allocation of financial resources and, most importantly, human well-being in cities (Dobbs et al., 2011), for locals and tourists, alike.

\section{Urban tourism and UGI uses}

While current international tourism trends are carving new territories, at the same time, they are reinforming older and more established patterns, creating further opportunities for niche tourism development, catering to existing and emerging special-interest and alternative tourism products (Hall et al, 2014; UNWTO, 2011; Hall and Page, 2006). Such proliferation and multiplication of tourism products goes hand-in-hand with the growth and prospects of lifestyle-, leisure- and wellness-oriented western ways of life and the outlook of their actual and potential relevance and applicability to the field of tourism (Chang and Huang, 2014; Huijbens, 2014; Iso-Ahola, 1982). In the context of the current attempt at greening European economies, nature-based solutions, options and possibilities seem to be at the forefront of these trends, also including new ways of incorporating open spaces and blue zones into urban life (UNWTO and UNEP, 2011).

Urban tourism is at the forefront of these developments, by virtue of its nature as an evertransforming and multi-layered set of recreational and cultural experiences, offering the potential for an endless series of combinations in the supply sector of tourism products, services, amenities, infrastructures, activities and experiences (Selby, 2012; UNWTO, 2011; Crouch, 1999; Page 1995; Urry 1995). Urban tourism acquires a multitude of forms and caters to a wide variety of specialinterest tourism niches, including cultural tourism, shopping, nightlife, sight-seeing, health etc. Each one of these types of urban tourism offers a variety of ways in which various forms of green infrastructure may enhance, compliment, support, or improve the tourist experience-and vice versa.

Although most common and established forms and variations of urban tourism are not motivated by or targeted towards UGI use and enjoyment, the latter inevitably become an often indispensable 
part of the tourism experience, consciously or spontaneously, intentionally or circumstantially, in the course of the visit to destination cities (Terkenli, 1996). In cases of more conventional forms of urban tourism, tourists do not seem to be much influenced in their choice of visited destination by the presence there of UGI or not. Normally, they do not initially intend to use UGI during their visit to these cities, but may do so circumstantially and incidentally, in the course of their urban tourism. On the basis of widely acknowledged UGI benefits shown to enrich urban life and experience, such benefits are also expected to contribute to the urban leisure experience of visitors, albeit in probably different ways, with variable results and implications (MEA, 2005; Kaplan and Kaplan, 1989). This field of inquiry, however, still remains, for the most part, uncharted territory. Moreover, not all types of urban tourist destinations cater to tourists' needs, preferences and aspirations, in similar or comparable ways. Such differences seem to stand out especially in cross-cultural studies of urban tourist uses, perceptions and preferences of UGIs (Terkenli et al, 2017).

UGI potentially serves the needs of both inhabitants and visitors. Konijnendijk et al. (2013), for instance, reviewing the benefits of urban parks, considered tourism as one of the major benefits (see notes about destination parks in the introduction). Greenways of high recreational, visual and historical value also tend to attract tourists (Fábos, 1995). Several studies examine users' perceptions, attachments, motives, preferences, practices, behaviours and factors influencing visits to urban forests. Bell et al. (2007), mapping research priorities for green space in the UK, highlighted the lack of baseline data at that time on people's use of parks and other green space as a first crosscutting theme to be addressed by future research. This included basic research concerning who does and does not use green space, categorized by social group, age group, gender, ethnic group and patterns of use over time and in relation to age/life stage. However, such knowledge has yet to be adequately developed in terms of tourist use of UGI. Little is also known about the interactions between the structural characteristics of UGI and use patterns related to the tourists' areas of provenance/residence. Likewise, little attention has been paid to the link between visitor characteristics and their behaviour regarding recreational activities.

Konijnendijk et al. (2013), concluded that there are some indications that parks have tourism benefits, but the strength of the evidence is weak, due to the very small number of studies, as well as the quality of those studies. However, several authors mention that green spaces may play an important role in attracting tourists to urban areas, e.g., by enhancing the attractiveness of cities and as a complement to other urban attractions (Majumdar et al., 2011), or that aesthetic, historical and recreational values of urban parks increase the attractiveness of the city, in its promotion as tourist destination, thus generating employment and revenues (Chiesura, 2004). Hansmann et al. 
(2016) also showed that tourism is one of the objectives of urban forest partnerships that are becoming increasingly popular around Europe.

Andrada and Deng, in a study in Washington, D.C. (2010), showed that most visitors were familiar with the benefits of urban forests as a tourist destination to enhance their enjoyment. Their findings provide managers with a clearer picture of what visitors like and enjoy while spending time in the city (Andrada and Deng, 2010). It is important to replicate and expand the scope and depth of such studies in other cultural contexts, both in Europe and elsewhere.

Finally, another very significant aspect of the roles UGI plays in all forms of urban tourism lies in the context of place and city branding, a sector of the tourism industry that has increasingly been gaining global momentum and application (Payne et al., 2009; Berry, 2000; Aaker, 1996). Integrating UGI into city branding is being recognized as an effective strategy for enhancing city attractiveness (Gulsrud et al., 2013) though such recognition is limited (Chan and Marafa, 2014).

\section{Methodology}

With the aim of collecting primary data on tourists' uses of UGI, at an exploratory level (indicative trends), a cross-cultural comparative study was conducted during 2015. Tourists were interviewed in 16 cities located in eight European countries: The Czech Republic (Kromeriz and Brno), Greece (Athens and Mytiline), Latvia (Riga and Jelgava), Lithuania (Birštonas and Kaunas), Portugal (Lisbon and Faro), Slovakia (Trencin and Bratislava), Serbia (Belgrade and Novi Sad) and United Kingdom (London and Southampton).

The selection of case studies follows a roughly comparative logic, with surveys administered in selected Northern, Central and Southern European countries (see Figure 1 and Table 1). We used convenience sampling, according to the origins of the team which collaborated on the project within the scope of COST Action FP1204 "Green Infrastructure approach: linking environmental with social aspects in studying and managing urban forest" ${ }^{11}$, which ran from 2013 to 2017. In order to make our sample more heterogeneous and increase its representativeness at the destination level, one largesize city and one middle-size city were chosen in each country, with 50 participants from each urban destination being interviewed (100 participants in total per country). The most significant criterion

\footnotetext{
${ }^{1}$ COST Action FP1204 website: https://www.cost.eu/actions/FP1204/\#tabs/Name:overview and http://www.greeninurbs.com
} 
for the selection of our survey cases was the existence of urban tourism in both the larger and the smaller cities.

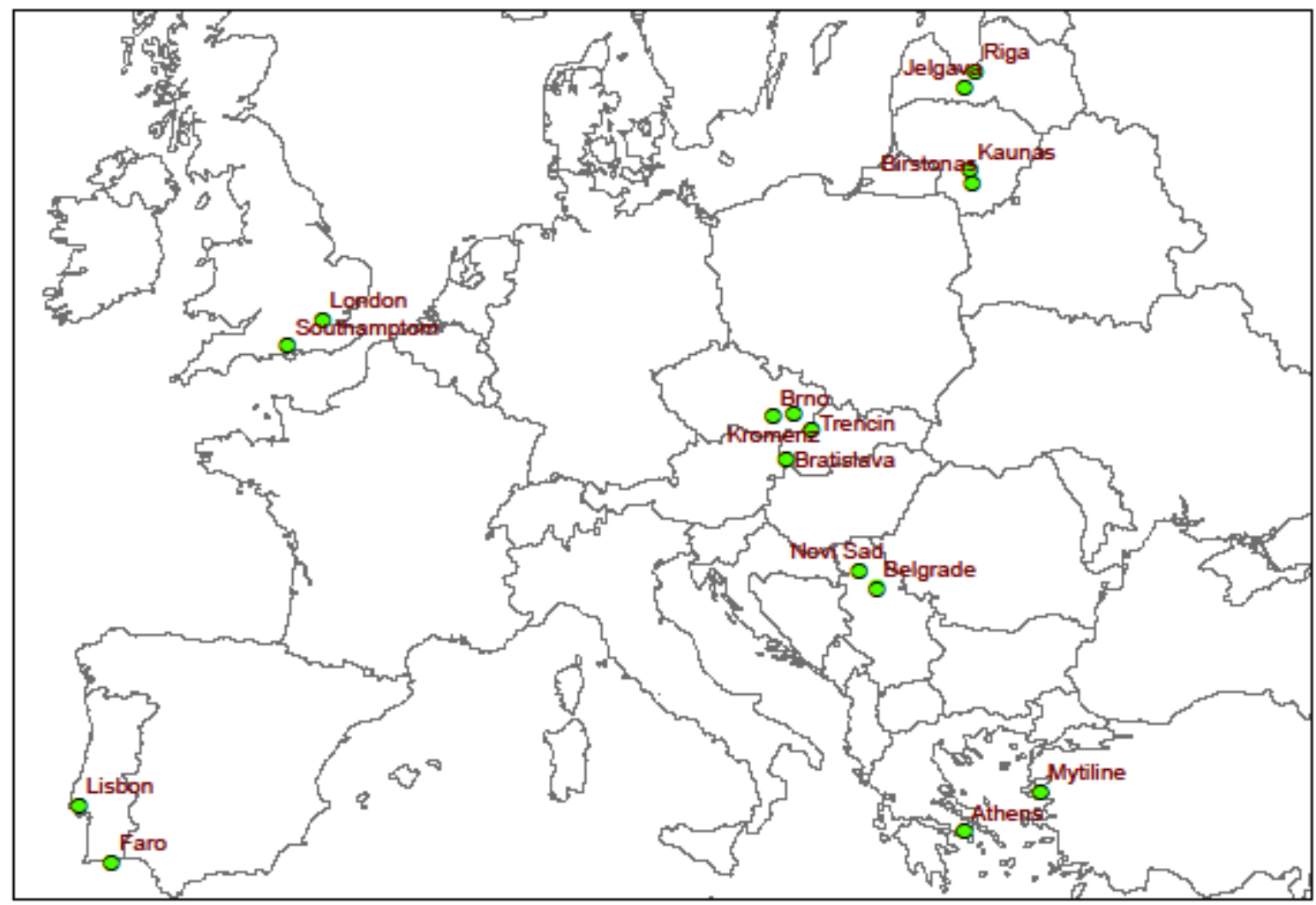

Figure 1. Case study sites of interview survey. Source: Lina Straigyte 
Table 1. European cities studied as case studies

\begin{tabular}{|c|c|c|c|c|}
\hline \\
\hline Case studies & Population & $\begin{array}{l}\text { Sample } \\
\text { size }\end{array}$ & Main forms of tourism & Main UGI types \\
\hline CZ-Brno & 377.508 & 51 & exhibition/congress tourism, cultural tourism & forests, landscape greenery, green areas, parks \\
\hline CZ-Kromeriz & 28.921 & 50 & cultural tourism & lawns, gardens, flowerbeds, woody plant areas \\
\hline GR-Athens & 3.827 .624 & 50 & $\begin{array}{l}\text { urban tourism, cultural/ archaeological } \\
\text { tourism, congress/ conference tourism }\end{array}$ & $\begin{array}{l}\text { parks, public open spaces/squares, public green } \\
\text { spaces, roadside verges, cemeteries, church yards }\end{array}$ \\
\hline GR-Mytiline & 37.890 & 50 & $\begin{array}{l}\text { urban/ cultural tourism, pilgrimage tourism, } \\
\text { gastronomic tourism }\end{array}$ & $\begin{array}{l}\text { parks, squares, public green spaces, private gardens, } \\
\text { coastline and roadside trees/ vegetation }\end{array}$ \\
\hline LV-Riga & 695.539 & 42 & $\begin{array}{l}\text { cultural tourism, sports tourism, spa/ health } \\
\text { tourism, business tourism }\end{array}$ & $\begin{array}{l}\text { forests, parks, squares, urban green spaces, roadside/ } \\
\text { riverside trees, private courtyards, cemeteries }\end{array}$ \\
\hline LV-Jelgava & 62.800 & 47 & $\begin{array}{l}\text { cultural tourism, natural resources tourism, } \\
\text { festival tourism }\end{array}$ & $\begin{array}{l}\text { forests, parks, squares, urban green spaces, roadside/ } \\
\text { riverside trees, private courtyards, cemeteries }\end{array}$ \\
\hline LI-Kaunas city & 299.466 & 48 & urban tourism & parks, public squares, forest \\
\hline LI-Birstonas & 2.461 & 50 & health tourism & forest park, urban forest, riverside promenade \\
\hline PT-Lisbon & 2.700 .000 & 51 & $\begin{array}{l}\text { cultural tourism, conference tourism, business } \\
\text { tourism, cruise tourism }\end{array}$ & $\begin{array}{l}\text { urban forest, parks, horticulture allotments, gardens } \\
\text { (public and private) }\end{array}$ \\
\hline PT-Faro & 42.615 & 49 & $\begin{array}{l}\text { sea-sun tourism, natural and cultural heritage } \\
\text { tourism }\end{array}$ & public green space, natural parks, sand-dune islands \\
\hline SR-Belgrade & 1.659 .440 & 50 & $\begin{array}{l}\text { cultural tourism, business /event tourism, } \\
\text { urban tourism }\end{array}$ & $\begin{array}{l}\text { parks, public green areas, squares, street-side and } \\
\text { river-bank vegetation, lawns }\end{array}$ \\
\hline SR-Novi Sad & 341.625 & 50 & $\begin{array}{l}\text { cultural tourism, natural resource tourism, } \\
\text { event tourism }\end{array}$ & $\begin{array}{l}\text { parks, public green areas, squares, street-side and } \\
\text { river-bank vegetation }\end{array}$ \\
\hline SK-Bratislava & 432.801 & 39 & $\begin{array}{l}\text { cultural tourism, congress/exhibition tourism, } \\
\text { business tourism, sports events tourism }\end{array}$ & $\begin{array}{l}\text { forests, parks, remnants of natural vegetation, } \\
\text { roadside verges, cemeteries }\end{array}$ \\
\hline SK-Trencin & 55.857 & 49 & $\begin{array}{l}\text { spa tourism, cultural tourism, winter sports } \\
\text { tourism, rural agro-tourism }\end{array}$ & $\begin{array}{l}\text { public parks, green areas of housing estates, forests, } \\
\text { tree-lined alleys, cemeteries, private gardens }\end{array}$ \\
\hline UK-London & 8.600 .000 & 34 & $\begin{array}{l}\text { urban tourism, cultural tourism, business } \\
\text { tourism, arts/entertainment tourism, shopping } \\
\text { tourism, higher education tourism }\end{array}$ & $\begin{array}{l}\text { parks, open spaces, railroad/road/waterways-side } \\
\text { vegetation/trees, nature conservation areas, } \\
\text { children's play areas, gardens }\end{array}$ \\
\hline $\begin{array}{l}\text { UK- } \\
\text { Southampton }\end{array}$ & 231.200 & 36 & $\begin{array}{l}\text { urban tourism, cultural tourism, natural } \\
\text { resource tourism, education tourism }\end{array}$ & $\begin{array}{l}\text { parks, green spaces, natural/ semi-natural green } \\
\text { spaces, sport courts, allotments, cemeteries, amenity } \\
\text { green spaces, }\end{array}$ \\
\hline
\end{tabular}


In order to assess and interpret tourists' practices, uses and behaviours vis-à-vis UGI, in the cities or towns of their destinations, an intensive survey questionnaire was designed. It consisted of a combination of different types of questions: closed-ended questions (yes/no, multiple-choice or a Likert scale of evaluation), as well as open-ended questions. The combination of different types of questions was employed to investigate the various dimensions of the views of the respondents and, particularly, to ensure that accurate information was obtained (Tomićević, 2005).

The questionnaire contained 28 questions, divided into five groups of questions. The first group of questions was related to perceptions towards UGI. In the second group, the questions were related to psychological aspects and preferences of respondents. The third group was related to behaviour and activities questions. The fourth group consisted of general questions related to how tourists use UGI in the city, what kinds of UGI tourists like, and how tourists prefer to use UGI. The last group addressed the socio-economic status of visitors and questions related to their travel experience. At the end of the survey respondents had the opportunity to provide personal comments as to why they chose to visit this particular city and what other activities they planned to do during their visit to the city. Supplementary material 1 presents the survey instrument.

The questionnaire was first pilot-tested in Greece and amended according to comments obtained through it. The data were collected during the spring and summer of 2015 , by means of a face-toface survey, from a total sample of 746 respondents (consisting only of foreign tourists). The questionnaire was implemented towards the end of the tourists' stay at the survey sites, and specifically at the appropriate ports of tourist exit from country, such as airports, ports, and train stations. Respondents were approached randomly.

The data were sorted using Microsoft Office Excel 2007, and subsequently analysed in SPSS software (Statistical Package for Social Sciences version 22) (SPSS, Chicago, IL.), which then provided data presented in graphs and tables. The parameters of the mean and standard deviations were used for the numerical variables and frequencies and percentages were used for the categorical variables (gender, age group, marital status, level of education, income).

The collected data were processed using both descriptive and inferential statistics. We extracted data related to the socio-economic characteristics of our sample, and correlated them with indices we created for the purpose of this research in order to get more quality data. These indices were formed based on the similarity or affinity of their item content and validated through principal factor analysis. For all four indices, one factorial solution was accepted, according to the Guttman Kaiser 
criterion (eigenvalues above 1), explaining $40.76 \%, 53.81 \%, 33.91 \%$ and $61.25 \%$ of variance respectively. These four indices are: Interest in UGI (combining questions 2, 4, 5, and 6), Intention to use UGI (combining questions 10,11 and 12), Willingness to pay for visiting UGI (combining questions 14, 19 and two cost questions C and D) and Socio Economic Status - SES (combining education and income information; Baker, 2014). Results from the factor analyses, including structure matrices for all four indices are given in Table 2, and Cattell scree plots from same analyses are given in Annex 2.

Table 2: structure matrix for four different indices extracted from questionnaire

\begin{tabular}{|c|c|c|c|c|c|c|c|}
\hline Eigenvalue & 1.631 & Eigenvalue & 1.614 & Eigenvalue & 1.356 & Eigenvalue & 1.225 \\
\hline \%of variance explained & 40.76 & \%of variance & 53.81 & \%of variance & 33.91 & \%of variance & 61.25 \\
\hline \multicolumn{2}{|l|}{ Interest in UGI } & \multicolumn{2}{|l|}{ Intention using UGI } & \multicolumn{2}{|c|}{ Willingness to pay for UGI } & \multicolumn{2}{|l|}{ SES } \\
\hline Q4_knowing_on UGI & .753 & $\begin{array}{l}\text { Q11_usage planned } \\
\text { UGI }\end{array}$ & .779 & c_Cost_trip_total eur & .601 & Q24_Income & .783 \\
\hline $\begin{array}{l}\text { Q6_undestanding_influ } \\
\text { ence }\end{array}$ & .675 & Q12_time_at UGI & .737 & $\begin{array}{l}\text { Q19_HowLong } \\
\text { hours }\end{array}$ & .601 & Q22_Education & .783 \\
\hline Q5_informing_on UGI & .659 & Q10_usage UGI & .682 & $\begin{array}{l}\text { Q14_Girole_city_cho } \\
\text { ose }\end{array}$ & .589 & & \\
\hline Q2_undestading UGI & .416 & & & d_Cost_visit_UGI eur & .536 & & \\
\hline
\end{tabular}

According to our research aims, data were further analysed in three subsections:

- For analysing differences between socio-economic characteristics in UGI use and perception, we applied one-way analysis of variance (ANOVA) and independent samples t test.

- Then we grouped respondents based on their country of origin, in order to get a more nuanced picture on the preferences regarding UGI. We divided our respondents into the following four groups: North Europe, Central Europe, South Europe and Out of Europe (Annex 1), and tested differences in UGI use and perception. In order to extract correlations between these country groups with other specific questions, we applied the chi-squared test, to determine whether there is a significant difference between the expected frequencies and the observed frequencies in one or more categories.

- Differences in UGI use and perception by country of destination were tested by one-way analysis of variance (ANOVA). For countries of destination we first tested differences between all visited countries, and then we grouped them into three groups Mediterranean, Baltic and Central European (UK was left out of this grouping, as it does not neatly fit in this type of regional distribution of our case studies).

Domestic tourists, whose trip originated from the same country in which the questionnaire was administered, were excluded from further analyses-they constituted only $5.6 \%$ of the total sample. 


\section{Results}

\section{Tourists' socio-demographic characteristics}

Most of our respondents belonged to the age category of $25-45$ years (37.9\%), followed by the youngest cohort of the sample (those under 25 , by $31.1 \%$ ). The age group of $45-66$ was represented by $19.5 \%$ of the sample and that of over 66 by $11.5 \%$.

Degree of interest in and willingness to pay for UGI

One-way analysis of variance (ANOVA) showed significant differences between age groups on proposed indices (Figure 2). The 25-45 cohort appeared to have a lower intention to use UGI than other cohorts (under $25,45-66$ and over 66$)(F(3 ; 739)=7.04 ; p<0.01)$. The age group 46-65 showed the highest willingness to pay for the use of UGI $(F(3 ; 736)=4.67 ; p<0.01)$, while the youngest (under 25 ) and oldest (over 66) showed the lowest willingness to pay for the use of UGI .

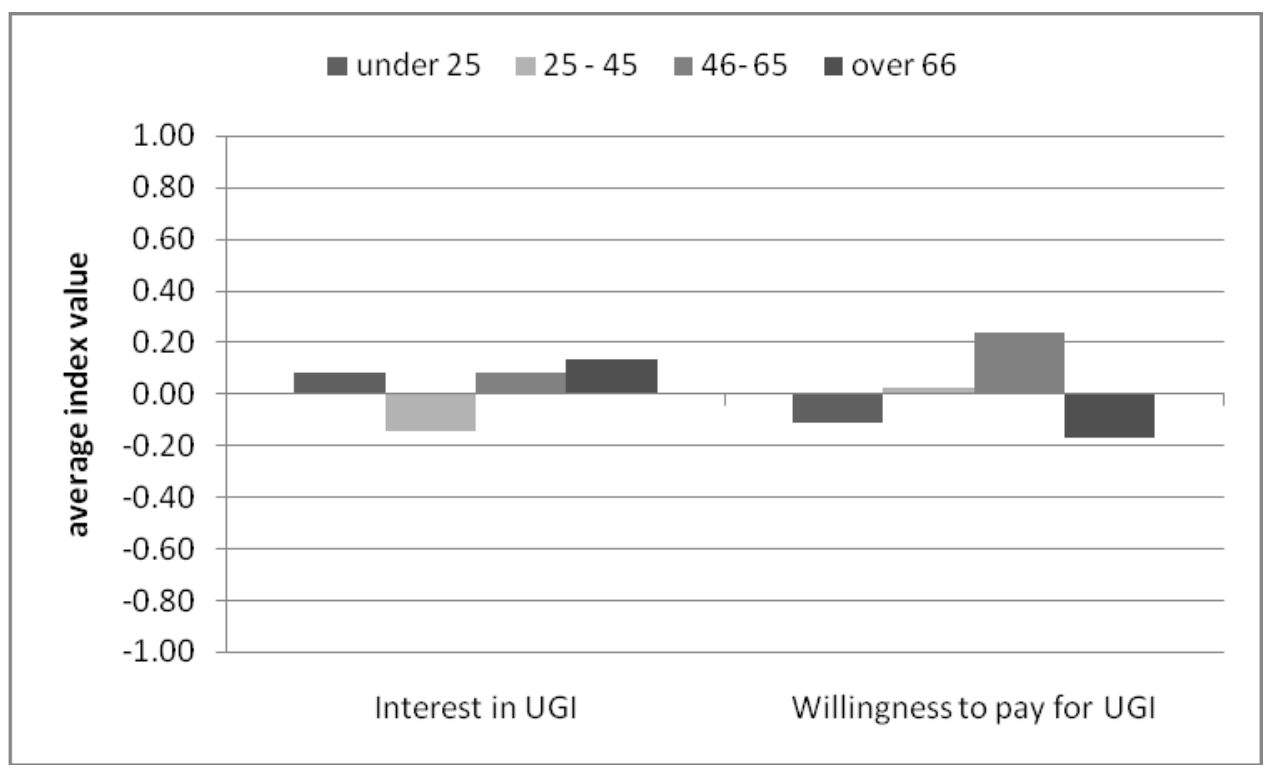

Figure 2: Average values of interest in and willingness to pay indices by age group (all scores are in standardized units).

In terms of gender, the ratio of surveyed male and female respondents was almost equal. The t-test for independent samples (differences between gender groups on proposed indices) showed that females declared a higher intention to use UGI $(t(741)=-2.35 ; p<0.05)$.

\footnotetext{
${ }^{2}$ Only results regarding statistically significant differences are shown on all graphs in the text
} 
There were no statistically significant differences with regard to interest in UGI, intention to use UGI or willingness to pay for the use of UGI, between the categories of respondents who were married or partnered $(47.6 \%)$, those who were single $(45 \%)$ and those belonging to the category "married with children" (7.4\%). On the other hand, proposed indices' values differed among various types of travellers (with whom participants travelled) (Figure 3). The highest interest $(F(4 ; 731)=4.32 ; p<0.01)$ and intention to use UGI $(F(4 ; 729)=4.90 ; p<0.01)$ were quoted by those who travelled with friends, while the highest willingness to pay for the use of UGI $(F(4 ; 727)=8.47 ; p<0.01)$ appeared among those who travelled with children and family.

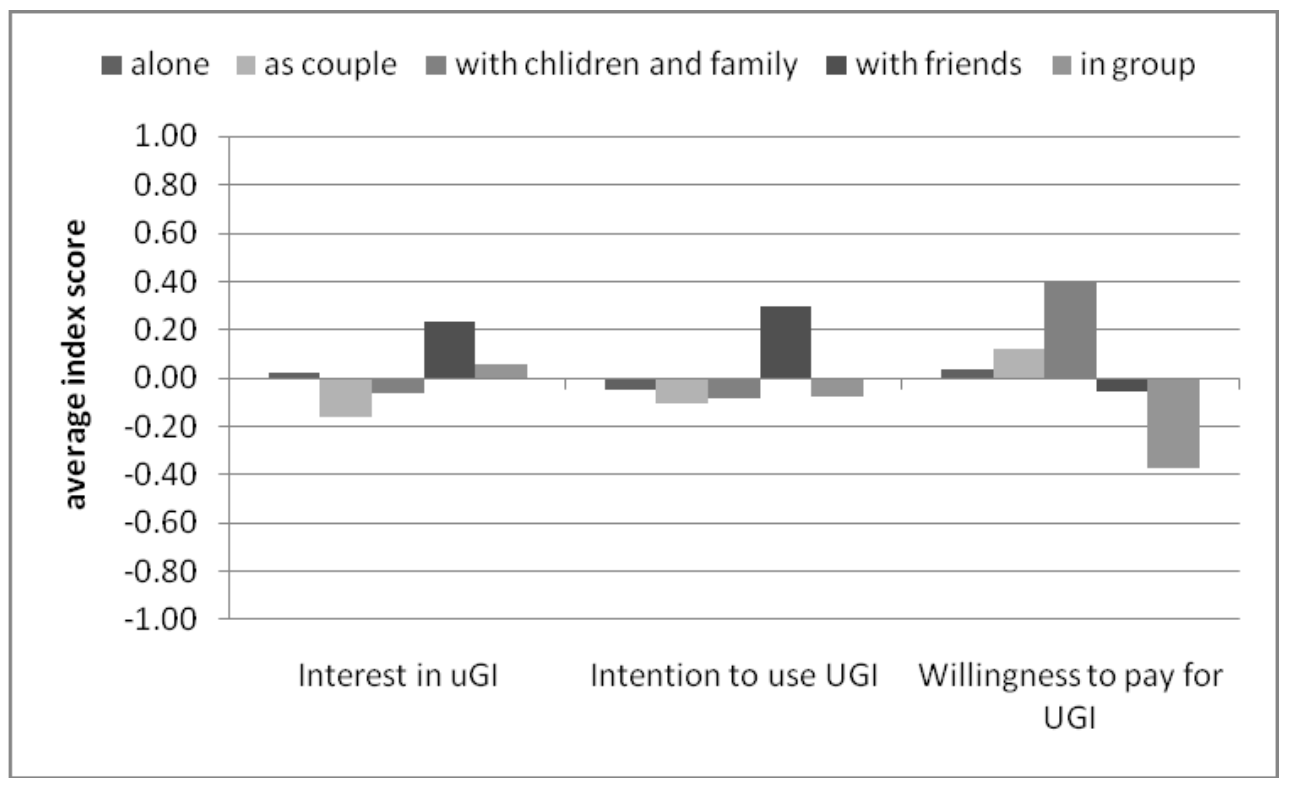

Figure 3: Average values of interest, intention to use and willingness to pay indices for different ways of travelling (all scores are in standardized units)

In terms of education, more than a half of the sample held university degrees (58.4\%), while $10.1 \%$ of the respondents also had had post-graduate or PhD education. The ANOVA test showed that higher levels of education correlated with higher willingness to pay for UGI $(F(3 ; 731)=5.23 ; p<0.01)$

In terms of income level, more than a half of all our respondents seemed to belong to the category of low and below average income (in total $67.2 \%)$; followed by average income (21.9\%) and above average $(6.9 \%)$ or high income $(4.1 \%)$. Since this is sensitive information, responses to the income question were not obtained from $4.4 \%$ of the sample. It must be also noted that this question was adapted to local circumstances; thus, the different income categories were calibrated for the different countries. ANOVA tests showed that low income groups correlated with the highest interest in UGI $(F(4 ; 708)=4.20 ; p<0.01)$, whereas middle income (30000-80000 EURO) groups showed the highest willingness to pay for use of UGI $(F(4 ; 703)=7.28 ; p<0.01)$ (Figure 4$)$. 


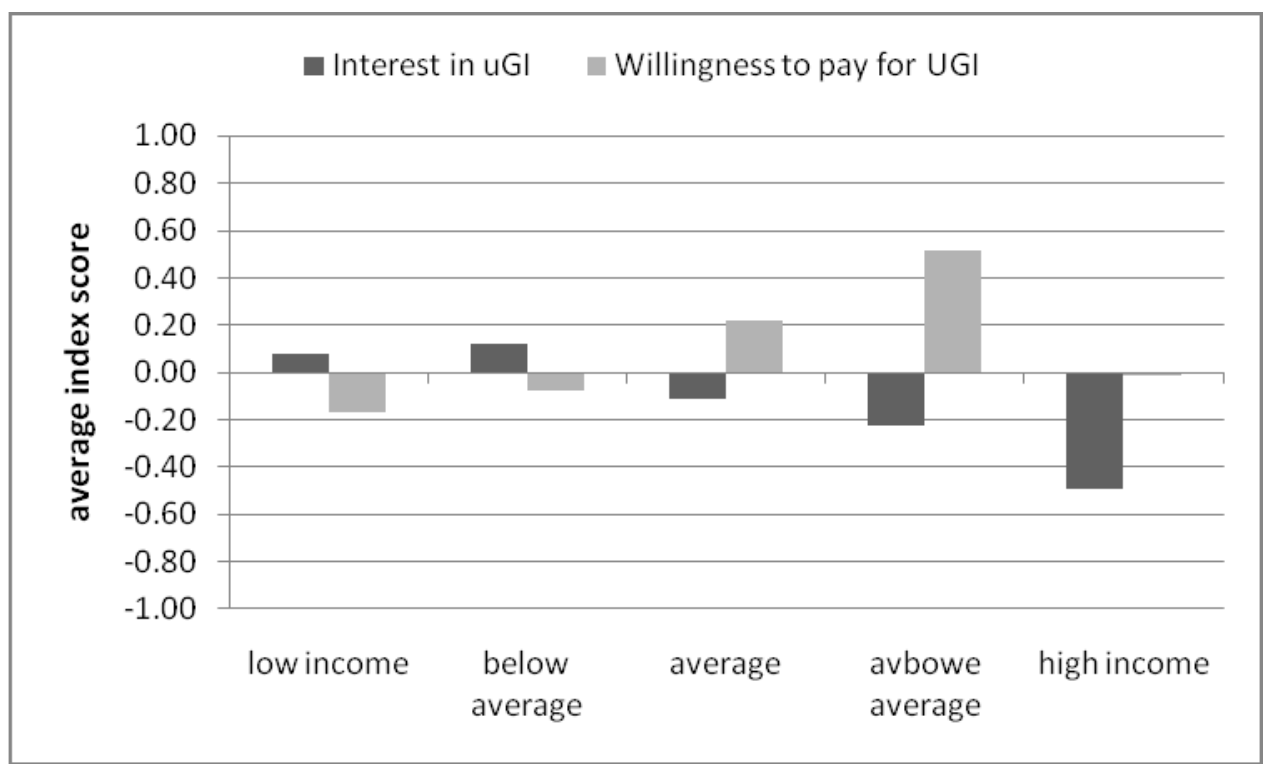

Figure 4: Average values of interest, intention to use and willingness to pay indices for different participant income levels (all scores are in standardized units)

Most of the interviewed tourists selected "pleasure" as the purpose of their visit (87.8\%), while just $10.1 \%$ responded that they were on business, or both $(2.2 \%)$. When asked what their status during this trip was, $14.4 \%$ said that they had travelled alone and $35.3 \%$ as a couple, while the rest had travelled in some sort of a group (with children, friends, family, etc). The t-test for independent samples (differences between purposes of the trip groups on proposed indices) showed that intention to use UGI was higher among those travelling for pleasure than for those travelling for other reasons $(t(740)=2.97 ; p<0.01)$.

\section{UGI use - perception by country of origin}

In order to achieve a more detailed understanding of tourists' perspectives towards UGI, we divided respondents into four regional groups, based on their country of origin: Northern Europe, Central Europe, Southern Europe and Non-European.

In terms of which countries they visited, our sample showed a correlation with country of origin $\left(\chi^{2}(21)=435.16 ; p<0.01\right)$ : out of Europe tourists tend to go to the UK, tourists from northern Europe tend to go to Greece or Lithuania, tourists from central Europe tend to go to the Czech Republic or Slovakia, while tourists from southern Europe tend to go to Serbia (Table 3). Here we need to note that this is a specific characteristic of our sample. Most of the tourists (but not exclusively) visiting Serbia or Czech Republic and Slovakia comes from neighbouring countries, thus making this correlation even stronger. 
Table 3: Cross-tabulations between country of tourist origin and country of visit

\begin{tabular}{|c|c|c|c|c|c|c|c|c|c|c|}
\hline & & \multicolumn{8}{|c|}{ Country of research } & \multirow[b]{2}{*}{ Total } \\
\hline & & Greece & Serbia & Portugal & Latvia & Lithuania & Czech & Slovakia & UK & \\
\hline \multirow{4}{*}{ 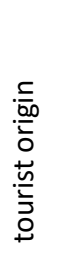 } & Non-European & 17 & 15 & 10 & 14 & 19 & 3 & 0 & 48 & 126 \\
\hline & Northern Europe & 42 & 10 & 23 & 16 & 39 & 8 & 5 & 5 & 148 \\
\hline & Central Europe & 35 & 23 & 42 & 28 & 35 & 88 & 75 & 7 & 333 \\
\hline & Southern Europe & 6 & 52 & 25 & 31 & 5 & 2 & 8 & 10 & 139 \\
\hline \multicolumn{2}{|c|}{ Total } & 100 & 100 & 100 & 89 & 98 & 101 & 88 & 70 & 746 \\
\hline
\end{tabular}

$\chi^{2}=435.16 ; \mathrm{df}=21 ; p=0.0001 ;$ Cramer's V $=0.441$

Next, and more importantly, we correlated groups of countries based on country of tourist origin with groups of visited countries (excluding UK, as it represents an exception in the composition of tourists), using a chi-square test. Not surprisingly, our analysis showed that non-European, southern and northern Europeans mostly visit Mediterranean countries, while, interestingly, central Europeans still tend to travel mostly within central Europe $\left(\chi^{2}(6)=159.24 ; p<0.01\right)$ (Table 4).

Table 4: Cross-tabulations between country of tourist origin and groups of visited countries

\begin{tabular}{|c|c|c|c|c|c|}
\hline & & \multicolumn{3}{|c|}{ Country grouped } & \multirow[b]{2}{*}{ Total } \\
\hline & & Mediterranean & Baltic & Central European & \\
\hline \multirow{4}{*}{ 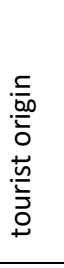 } & Non-European & 42 & 33 & 3 & 78 \\
\hline & North Europe & 75 & 55 & 13 & 143 \\
\hline & Central Europe & 100 & 63 & 163 & 326 \\
\hline & South Europe & 83 & 36 & 10 & 129 \\
\hline \multicolumn{2}{|c|}{ Total } & 300 & 187 & 189 & 676 \\
\hline
\end{tabular}

When respondents were asked how they understood UGI, most of them identified UGI with parks (83.2\%), with urban forests $(56.2 \%)$, or with green corridors $(49.2 \%)$. Other infrequent answers included gardens and open areas, or 'infrastructure that accounts for ecology issues', 'energy sustainable buildings', 'maintenance of environment'. These findings indicate that the term is ambiguously used and understood, pointing to a low-level of awareness by tourists of the UGI concept. However, although the concept did not seem to be well understood, the importance of UGI was generally seen in a positive light, with more than two-thirds of the respondents referring to UGI as somewhat important (71.1\%) or very important (5.3\%) to the visited city. This finding refers to the 
importance of UGI in terms of how tourists understood it, rather than to all possible meanings of UGI, and, therefore, it is mainly related to parks, urban forests and green corridors.

As regards the results and the significance of the question of UGI importance, the chi-square test showed that there were no statistically significant differences between tourists from different country groups, since they all equally pointed to environmental sustainability as the main reason why UGI is important.

The chi-square test further revealed a correlation between the groups of tourist origin countries and the question "which UGIs influenced your choice to visit [a certain city]?". Correlations show that central Europeans, compared to other tourist groups, focused the most on urban forests $\left(\chi^{2}(3)=16.69 ; p<0.01\right)$ and gardens $\left(\chi^{2}(3)=23.46 ; p<0.01\right)$ as a reason to visit a particular city, while northern Europeans chose parks $\left(\chi^{2}(3)=8.20 ; p<0.05\right)$ the most. Furthermore, it became apparent that cultural aspects of UGIs seem to be the most relevant to central European tourists at their urban destination $\left(\chi^{2}(3)=46.86 ; p<0.01\right)$, while green corridors seemed to be the option least selected by central European tourists $\left(\chi^{2}(3)=14.63 ; p<0.01\right)$. For other types of green areas (lawns, other green elements, water etc.) no significant correlations emerged.

Most of the interviewed tourists declared that they use UGI for walking $(70.2 \%)$, and less so for other activities. Furthermore, they declared that they intended to visit particular parks $(70.6 \%)$ in destination cities more so than other categories of UGI. In connection with their poor understanding of UGI, this finding indicates that they mainly identify UGI with parks.

Regarding the question of how respondents used UGI, chi-square tests revealed that the central European tourist group quoted relaxation more than any other group $\left(\chi^{2}(3)=41.81 ; p<0.01\right)$, whereas non-European tourists responded that they used UGIs for sightseeing $(\chi 2(3)=9.22 ; p<0.05)$ and socializing $(\chi 2(3)=44.37 ; p<0.01)$ more than any other group (Figure 5$)$. No other UGI use appears to be significantly correlated with any of the country groupings tested. 


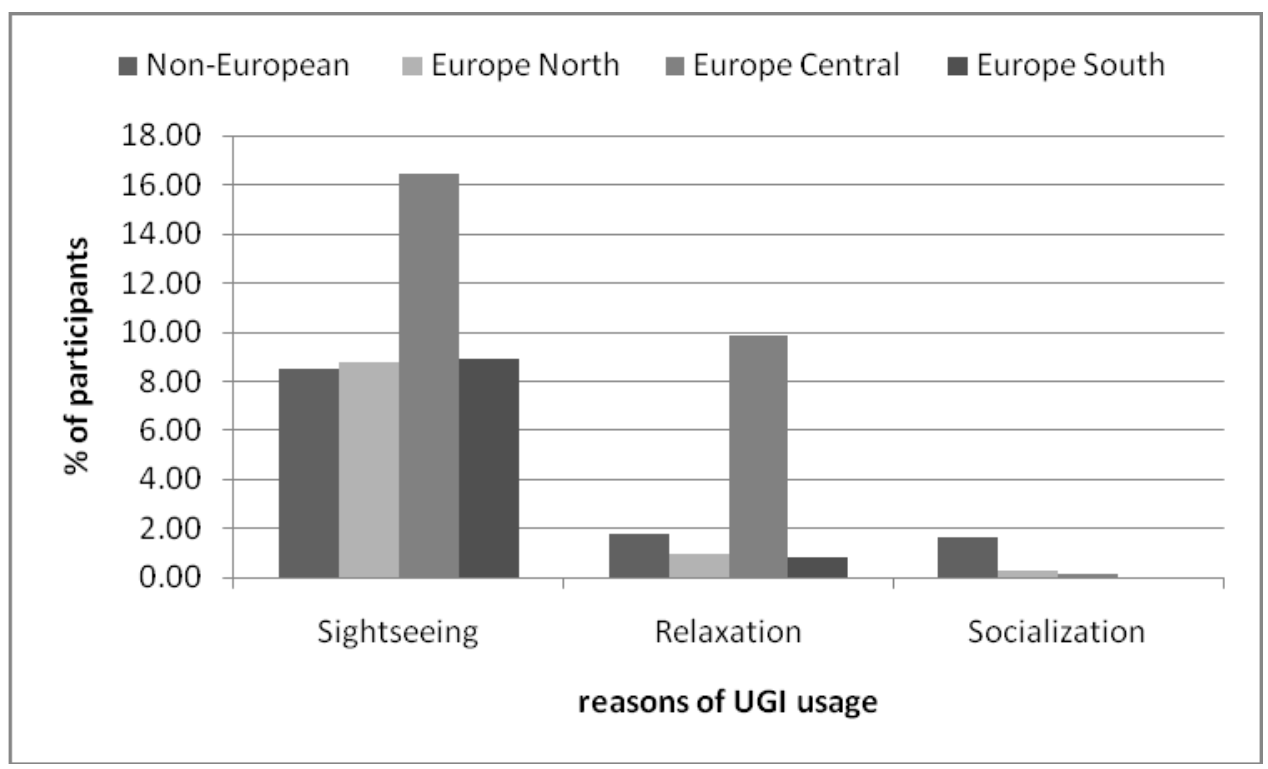

Figure 5: UGI tourist uses by geographic origin

The majority of respondents stated that they planned to spend 1-2 hours using UGI in the cities they visited (49.5\%), followed by those who intended to spend 2-5 hours (23\%) and 5-10 hours (11.1\%). Only $16.4 \%$ responded that they would spend less time (fewer minutes) in those city areas. This leads us to conclude that, at least as far as interviewees declared, UGI represents important urban areas for visitation by tourists. Analysis of variance showed that the time spent using UGI does not differ significantly between different country groups.

\section{UGI use - perception by country of destination}

Finally, at the other end of the tourist practices studied, we looked in more detail at differences concerning destination countries, in terms of tourists' 'Interest in UGI', 'Intention to use UGI', 'Willingness to pay for UGI' and 'Socio-economic status - SES', by applying one-way analysis of variance (ANOVA) tests. The following table (Table 5) presents the significance of differences between means of all analysed scores, per country.

Table 5. Significant difference between means of individual countries on all four indices ('Interest in UGIs', 'Intention to use in UGI', 'Willingness to pay for UGI' and 'Socio Economic Status - SES')

\begin{tabular}{|c|c|c|c|c|}
\hline & Df1 & Df2 & $\mathrm{F}$ & $p$ \\
\hline Interest_in_UGI & $7 \mid$ & 738 & 43.011 & .000 \\
\hline Intention_to-use_UGI & 7 & 735 & 29.141 & .000 \\
\hline Willingness to pay for_UGI & 7 & 732 & 12.148 & .000 \\
\hline
\end{tabular}




\begin{tabular}{l|r|r|r|r}
\hline SES & 7 & 737 & 14.656 & $\mathbf{0 0 0}$ \\
\hline
\end{tabular}

Table 5 indicates that tests for all 4 scores are significant $(p<.1)$, suggesting that countries of tourist destination in our survey differ on all four indices. Looking at the countries separately, it can be deduced that interest in UGI seems to be highest in the Czech Republic $(\bar{x}=-0.91)$ and lowest in Portugal ( $\bar{x}=-0.88)$ (Figure 6).

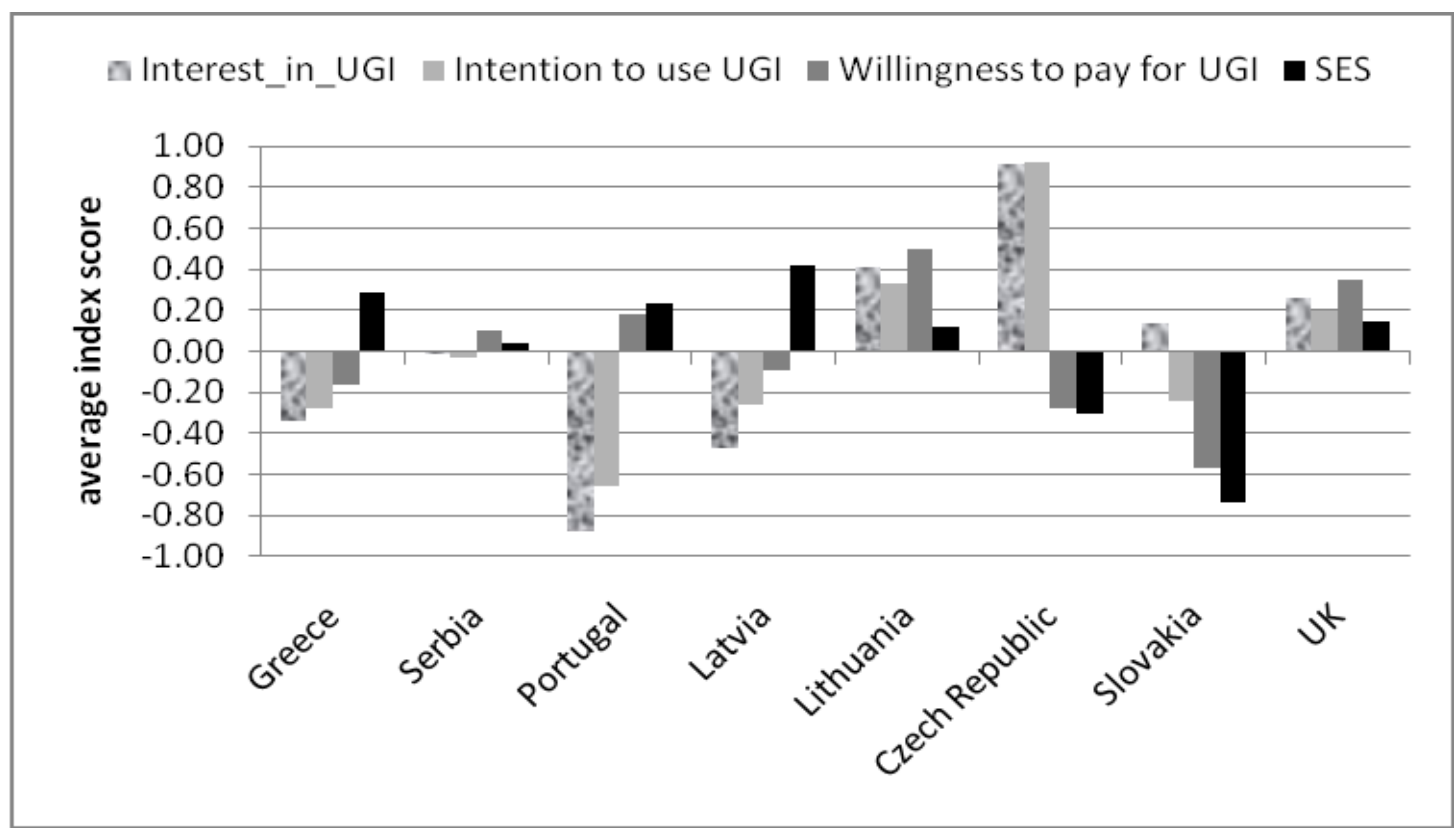

Figure 6: Differences between countries on all four indices ('Interest in UGIs', 'Intention to use in UGI', 'Willingness to pay for UGI' and 'Socio Economic Status - SES') (all scores are in standardized units)

Furthermore, the intention to use UGI seemed to be highest in The Czech Republic $(\bar{x}=0.92)$ and lowest in Portugal ( $\bar{x}=-0.66)$. Willingness to pay for UGI seemed to be highest in Lithuania $(\bar{x}=0.50)$ and lowest in Slovakia ( $\bar{x}=-0.57$. Finally, tourists' SES appeared to be highest in Latvia $(\bar{x}=0.42$ ) and lowest in Slovakia ( $\bar{x}=-0.74$ ) (Figure 6).

\section{Discussion and conclusions}

\section{Validation of other research}

Besides verifying some expected trends in tourists' uses of UGI, on the basis of the scientific literature (Chang and Huang, 2014; Hall and Page, 2006; Hall et al., 2014; Majumdar et al., 2011; Page 1995; Selby, M., 2012), our findings reveal interesting aspects and prospects vis-à-vis our 
subject matter. There were no surprises in the results pertaining to the socio-demographic characteristics of our sample, as related to tourist attitudes, perceptions and practices in UGI use and understanding. Based on our research sample, results show that the 25-45 age group showed the lowest intention to use UGI, whereas 45-66 year-olds indicated that they were more willing to pay for such uses. The overall income status of our respondents shows that low and below-average income categories are most involved in urban tourism, in the context of this study. The low-cost or free use of UGIs makes them accessible to almost all tourist categories. The educational level among our sample of European tourists was fairly to quite high, as expected according to (Altbach et al., 2019; WTO/ETC, 2005; Hayllar et al. 2008). Naturally, the propensity to use UGI appeared to be higher among pleasure tourists, than among business tourists, based on their travel plans. Moreover, the declared interest in and intention to use UGI was highest among tourists travelling with friends, while families showed a greater willingness to pay, despite their lower intentions to use UGIs, in the first place. Tourists travelling in groups showed the lowest intention to pay for UGI services.

\section{Trends in tourism patterns}

A well-established trend in international tourism patterns (UNWTO 2011) was validated by our data concerning tourists' countries of origin: namely the fact that neighbouring countries tend to be most significant tourist markets of an urban destination, i.e. our Lithuanian sample receives most of its incoming tourism from Northern or Central Europe, and the Czech and Slovak Republics from Central Europe (Table 3). This tendency, is, of course, tempered by a variety of other factors, such as whether a country is a seaside ' $3 S^{\prime}$ ' (sun, sea and sand) tourism destination, whether it is landlocked and other socio-economic characteristics of its tourist demand. In the case of Central European destinations, such trends emerged from our research as very significant, suggesting the question as to whether such tourist movement patterns illustrate a continuation of those typical of past 'SecondWorld' tourism (mainly internal tourist movements or restricted within the communist block (Witt, 2014)), an important finding that begs for further future investigation. Notwithstanding the fact that the UK remains a top global urban destination, generally speaking, the other major finding confirming most well-known tourist movement patterns was the indication that Northern Europeans and all others travel to the Mediterranean for tourism purposes (UNWTO 2011, Eurostat, 2019).

\section{Understanding of UGI as a term}

Tourists from all of our sample countries tended to associate the significance of UGI with environmental sustainability. Report from the World Tourism Organization and European Travel 
Commission shows that the natural environment is considered a more important motivator for travel compared to history in general, but as well that culture and historic towns and monuments were the most important attractions visited (WTO/ETC, 2005). Urban tourism in Europe largely coincides with cultural tourism -the latter represents the greatest part and component of the former (UNWTO 2011). Generally speaking, the fact that most large green infrastructure spaces in our study cities were located around or within short distances from important heritage sites, provided UGI with an indirect possibility of being included in the tourists' visiting plans and in some cases were destination parks (Terkenli et al., 2017). Moreover, taking into consideration the fact that UGI tends to be connected with public spaces/amenities and attractive city landscapes, this connection could be enhanced by further investigation and investment in the linkages between UGI and social/cultural activities, in such areas. This is confirmed by other studies which emphasise that UGI elements and heritage elements are the two core attractions that can jointly contribute to the sustainable development of the cities (Boivin and Tanguay, 2019; Yuan eta I., 2018).

Scholarly literature reveals that the role of green areas in urban tourism gains in relevance (Boivin and Tanguay, 2019; Yuan eta I., 2018; Mikulic et al., 2016). A study by Yuan et al. (2018) showed that one of the main attributes with which tourists were most satisfied when visiting Savannah in Georgia (USA) were the urban forest, comprising parks and gardens, tree-lines, public squares and trees in neighbourhoods. This was also the only attribute classified as an excitement factor, meaning that urban forests can provide experience to the visitors and generate potentially additional value. A study by Mikulic et al. (2016) emphasise that green areas are a potential satisfier element for tourists. Similarly, Boivin and Tanguay (2019) found that the living environment (including green areas) plays an essential role in the attractiveness of the city, emerging as more important than the nucleus comprising monuments and historic sites. Other studies point to historic or remarkable gardens as the most visited green spaces for tourists (Cianga and Popescu, 2013).

\section{Willingness to pay for UGI}

The correlation between SES and willingness to pay for the use of UGIs across destination countries reveals an interesting picture. It is generally expected that income is positively related to the valuation of nature (Jacobson and Hanley, 2009) which is partly confirmed by our findings. Namely, based on our sample, tourists visiting the Czech Republic and Slovakia show the lowest SES and accordingly the lowest willingness to pay for the use of UGIs, while tourists visiting Lithuania and the UK show the opposite trend: they quoted the highest SES and highest willingness to pay for the use of UGIs. Apart from that, tourists visiting Greece and Latvia showed the highest SES, but, on the 
other hand, declared quite low willingness to pay for the use of UGIs. Accordingly, our middleincome SES groups, as well as the more educated categories, showed a higher willingness to pay for the use of UGI compared with lower income categories, speaking for the totality of our sample.

\section{Conclusions}

In our study we asked four research questions and we summarise the answers as follows:

1. How do urban tourists perceive and understand UGI, in the context of their overall tourism experience? The study results revealed that the majority of the tourists we interveiwed were not very familiar with the term 'Green Infrastructure', nor with UGI features offered in the visited cities. As this is a fairly recent term coined by academics and professionals, it is hardly surprising, but once explained to respondents then it was generally understood. Parker and Zingoni de Baro (2019) in the first systematic review of green infrastructure research identified a degree of vagueness in definition and understanding of the term among researchers, so it is no surprise it is weak among the public. Our sample respondents mostly identified UGI to be parks, and less often green corridors or urban forests; some equated it with flower boxes, cycle paths, or ecofriendliness. However, although the concept of UGI did not seem to be well understood, its importance was acknowledged and viewed in a mostly very positive light.

2. How do urban tourists tend to use UGI, in the context of their overall tourism experience? The majority of our survey participants seemed to enjoy visiting UGI spaces, such as big parks or urban forests, mostly for some light physical activity or for purposes of relaxation, for socialising and in order to explore the culture and society of the destination city. Walking was overwhelmingly quoted by our interviewees as their main intended activity in connection with UGI, but Central European tourists also expressed a relative propensity to use UGIs for relaxation. Tourists generally seemed to care about UGI in these cities and the majority planned to visit UGI for more than an hour, a tendency similar across countries and regions of our sample.

3. How do these tourist perceptions and uses differ cross-culturally? Differences emerged on all four of our indices, namely 'Interest in UGI', 'Intention to use UGI', 'Willingness to pay for UGI' and 'Socio-economic status - SES'. Interest in and intention to use UGls was lowest among tourists who visited mainly Southern/ Mediterranean urban destinations (with the exclusion of Latvia), as opposed to Central and Northern European ones, due to the nature of the latter urban destinations, which tend to feature more, more attractive, and perhaps even better-tended UGI, rather than the former ones. In contrast, the Southern/ Mediterranean urban destinations 
represent summer and seaside ' $3 \mathrm{~S}^{\prime}$ ' destinations, with an additional emphasis on cultural heritage (Table 1).

4. How do these tourist perceptions and uses differ in terms of their destination country/region? There were no specific differences in perceptions or understanding but while the selected UGls for Northern Europeans seemed to be parks (perhaps illustrating in-grained activities from their countries of origin), Central Europeans opted for a wider range of UGI, such as urban forests and gardens, in significant connection with cultural aspects of UGI.

Even though urban tourism has major economic importance it is still evident that little attention has been given to the question how tourists actually use cities (Ashworth and Page, 2011). Thus, the results of the present survey may prove to be very helpful in this regards, and add some understanding of the tourists' perception toward UGI. We believe that the results are also of relevance to local and regional authorities in the planning and management of an urban tourist destination's green infrastructure. Examples of certain cities, famous and recognised by their distinctive green areas (e.g. the Hyde Park in London, Parc Güell in Barcelona or New York's Central Park, etc.), illustrate how UGI can play a significant role in building a city brand or image, and, thus, in attracting tourist visits (Konijnendijk, 2008). Studies from Boivin and Tanguay, 2019; Yuan et al., 2018; Mikulic et al., 2016, also highlight the very prominent role of UGI concerning tourists use of cities. However, more comprehensive and cross-sectoral approaches must be adopted by city actors, in connection with the nature and UGI characteristics of these cities as tourist destinations, as well as the types/forms of tourism they support and attract, as emphasised in Shoval, 2018.

Edwards et al. (2008, p. 1038) state that urban tourism is "one among many social and economic forces in the urban environment. It encompasses an industry that manages and markets a variety of products and experiences to people who have a wide range of motivations, preferences and cultural perspectives and are involved in a dialectic engagement with the host community". Thus, various viewpoints need to be merged in strategies for sustainable urban tourism which could potentially lead to increased city attractiveness. The role of the urban living environment should not be overlooked (Boivin and Tanguay, 2019). Addressing city attractiveness from a sustainability perspective can help to avoid the danger of over-tourism, but at the same time profit from increased appreciation and value of green and sustainable environments among tourists and the urban population in general. 
In order to enhance existing urban tourism development patterns, two directions may be followed: either the reinforcement of existing patterns, in order to establish these destinations competitively in the global tourism industry, or a diversification of them, by fostering tourism growth towards compensation vis-à-vis those areas lacking tourist demand-and thus eliminating local and regional or European-wide imbalances in tourism development. The latter alternative, if desirable, may be achieved through appropriate and concerted marketing/branding of destinations and the development of necessary UGI infrastructures from the supply side (i.e. parks, waterways etc).

\section{Limitations and further research}

Clearly, given the limited and unrepresentative sample cities used in this research and limited understanding of UGI term by the respondents, additional and more in-depth studies aiming to obtain a broader and more reliable picture are necessary. Such research could then build stronger recommendations on the measures, methods and interventions in UGI to be undertaken by UGI managers, towards the enhancement of a city's UGI uses and its attractiveness to tourists. Public perception surveys aiming at further investigating tourists' perceptions, preferences and uses of UGI, in various contexts and at different urban scales, would enable green infrastructure managers to identify preferred management alternatives and put this information to better use in future urban planning and tourism development projects and frameworks.

\section{Acknowledgements}

This article was produced as part of the COST Action FP1204 "Green Infrastructure approach: linking environmental with social aspects in studying and managing urban forest" (GreenInUrbs), which ran from 2013 to 2017. The authors would like to thank the Action for its support in enabling the work and interaction between the researchers required for the article. 


\section{References}

Aaker, D., 1996. Building Strong Brands. New York: Free Press.

Altbach, P.G., Reisberg, L., Rumbley, L.E. 2019. Trends in Global Higher Education: Tracking and Academic Revolution. UNESCO Publishing, France, Sense Publishers, Netherlands, p. 168.

Andrada, R., Deng, J., 2010. Enjoying green cities: assessing visitors' attitudes and preferences for urban forests in Washington, D. C. Proceedings of the 2010 Northeastern Recreation Research Symposium GTR-NRS-P-94, 168-174.

Ashworth, G., Page, S.J. 2011. Urban tourism research: recent progress and current paradoxes. Tourism Management 32, 1-15.

Baker, E. H. (2014). Socioeconomic status, definition. The Wiley Blackwell Encyclopedia of Health, Illness, Behavior, and Society, 2210-2214.

Bell, S., 2008. Design for Outdoor Recreation. Taylor \& Francis, London.

Berry, L.L., 2000. Cultivating service brand equity. Journal of the Academy of Marketing Science, 28 (1), 128-137.

Berte E., Panagopoulos T., 2014. Enhancing city resilience to climate change by means of ecosystem services improvement: a SWOT analysis for the city of Faro, Portugal. International Journal of Urban Sustainable Development. 6, 241-253. http://dx.doi.org/10.1080/19463138.2014.953536

Boivin, M., Tanguay, G.A. 2019. Analysis of the determinants of urban tourism attractiveness: The case of Quebec city and Bordeaux. Journal of Destination Marketing and management 11, 67-79.

Canadas, M.J., Novais, A., 2014. Bringing local socioeconomic context to the analysis of forest owners' management. Land Use Policy 41, 397-407

Carrus G., Dadvand P., Sanesi G., 2017. The Role and Value of Urban Forests and Green Infrastructure in Promoting Human Health and Wellbeing. In: Pearlmutter D. et al. (eds) The Urban Forest. Future City, vol 7. Springer, Cham

Cekule, M., 2010. Rīgas telpiskās struktūras analīze, izmantojot ǵeogrāfiskās informācijas sistēmas [Riga's city spatial strukture analyse based on geographical information system]. Doctoral thesis, University of Latvia, Riga, Latvia. (in Latvian)

Cianga N., Popescu C.A., 2013. Green Spaces And Urban Tourism Development in Craiova Municipality In Romania, European Journal of Geography 4(2), 34-45. 
Chang, T.C., Huang, S., 2014. Urban tourism and the experience economy. In: Lew, A. A.; Hall, C. M., Williams, A. M. (eds.) The Wiley-Blackwell Companion to Tourism. Wiley Blackwell, Oxford.

Chan, C.-S., \& Marafa, L. M., 2014. Rebranding Hong Kong "Green": The potential for connecting city branding with green resources. World Leisure Journal, 56(1), 62-80. doi:10.1080/04419057.2013.876587

Chen, W.C., Jim, C.Y., 2008. Assessment and Valuation of the Ecosystem Services Provided by Urban Forests. In: M.M.Carreiro, Y.C.Song., J.Wu (Editors), Ecology, Planning, and Management of Urban Forests. International Perspectives. Springer, New York, pp. 53-83.

Chiesura, A., 2004. The role of urban parks for the sustainable city. Landscape and Urban Planning, 68(1), 129-138. doi:10.1016/j.landurbplan.2003.08.003

Crouch, D., 1999. Leisure/Tourism Geographies: Practices and Geographical Knowledge. Routledge, London.

Dobbs, C., Escobedo, F.J., Zipperer, W.C., 2011. A framework for developing urban forest ecosystem services and goods indicators. Landscape Urban Planning, 99, 196-206.

Dwyer, J.F., McPherson, G.E., Schroeder, H.W., Rowntree, R.A., 1992. Assessing benefits and costs of the urban forest. Journal of Arboriculture, 18(5), 227-234.

Eurostat, 2019. Tourism statistics https://ec.europa.eu/eurostat/statisticsexplained/index.php?title=Tourism statistics\&oldid=440644 (assessed 15 November 2019)

Edwards, D., Griffin, T., Hayllar, B. 2008. Urban tourism research: Developing an agenda. Annals of Tourism Research, 35(4), 1032-1052.

Eriksson, L., Nordlund, A., Olsson, O., Westin, K., 2012. Beliefs about urban fringe forests among urban residents in Sweden. Urban For. Urban Green. 11, 321-328.

Fábos, J.G., 1995. Introduction and overview: the greenway movement, uses and potentials of greenways. Landscape and Urban Planning, 33, 1-13.

Galečić, N., Tomićević-Dubljević, J., Ocokoljić, M., Vujičić, D., Skočajić, D., 2016. Quality and utilization potential of urban parks: case study Tašmajdan park, Belgrade, Serbia, Šumarski list, 9$10,493-501$

Gudurić, I., Tomićević, J., Konijnendijk, C.C., 2011. A comparative perspective of urban forestry in Belgrade, Serbia and Freiburg, Germany. Urban For. Urban Green. 10, 335-342. 
Gulsrud, N. M., Gooding, S., \& Konijnendijk Van Den Bosch, C. C., 2013. Green space branding in Denmark in an era of neoliberal governance. Urban Forestry \& Urban Greening, 12 (3), 330-337. doi:10.1016/j.ufug.2013.03.001

Gunnarsson, G., Øhrstroom, H.E., 2007. Noise and well-being in urban residential environments: the potential role of perceived availability to nearby green areas. Landscape and Urban Planning, 83, 115-126.

Hansmann, R., Whitehead, I., Krajter Ostoić, S., Živojinović, I., Stojanovska, M., Jones, N., Bernasconi, A., Benamar, S., Lelieveld, C., Barstad, J., 2016. Partnerships for urban forestry and green infrastructure delivering services to people and the environment: a review on what they are and aim to achieve. Southeast European Forestry, 7 (1) DOI: http://dx.doi.org/10.15177/seefor.16-09

Hall, C.M., Page, S.J., 2006. The Geography of Tourism and Recreation: Environment, Place and Space, Routledge, London.

Hall, C.M., Williams, A.M., Lew, A.A., 2014. Tourism: conceptualizations, disciplinarity, institutions, and Issues. In: Lew, A. A.; Hall, C. M., Williams, A. M. (eds.) The Wiley-Blackwell Companion to Tourism. Wiley Blackwell, Oxford.Huijbens, E., 2014. Natural wellness. The case of Icelandic wilderness landscapes for health and wellness tourism. In M. Smith \& L. Puczkó (Eds.) Health, Tourism and Hospitality: Spas, Wellness and Medical Travel. Routledge, London, 413-416.

Hayllar, B., Griffin, T., Edwards., D. (2008) City Spaces - Tourist Places: Urban Tourism Precincts, Butterworth-Heinemann is an imprint of Elsevier, Oxford, UK \& Burlington, USA.

Iso-Ahola, S. E. 1982. Toward a social psychological theory of tourism motivation: a rejoinder. Annals of Tourism Research, 9 (2), 256-261.

Jacobson, J.B., Hanley, N. (2009). Are there income effects on global Willingness to Pay for biodiversity conservation? Environment and Resource Economics, 43 :137-160.

Jankovska, I., Straupe, I., Panagopoulos, T., 2010. Professionals' awareness in promotion of conservation and management of urban forests as green infrastructure of Riga, Latvia. WSEAS Transactions on Environment and Development, 6, 614-623.

Jankovska, I., Donis, J., Straupe, I., Panagopoulos, T., Kupfere, L., 2013. Assessment of the forest recreation accessibility in Latvia. Fresenius Environmental Bulletin. 22, (7B), 2145-2151.

Jankovska, I., Straupe, I., Brumelis, G., Donis, J., Kupfere, L., 2014. Urban forests of Riga, Latvia pressures, naturalness, attitudes and management. Baltic Forestry, 20 (2), 342-351. 
Kaplan, R., Kaplan, S., 1989. The Experience of Nature. A psychological perspective. Cambridge University Press, Cambridge.

Karppinen, H., Berghäll, S., 2015. Forest owners' stand improvement decisions: applying the theory of planned behavior. Forest Policy Econ. 50, 275-284.

Konijnendijk, C.C., 2008. The Forest and the City: The cultural landscape of urban woodland. Springer, Berlin.

Konijnendijk, C.C., Annerstedt, M., Busse Nielsen, A., Maruthaveeran, S., 2013. Benefits of urban parks a systematic review. International Federation of Parks and Recreation Administration, Copenhagen/Alnarp, 1-70.

Konijnendijk, C.C., Randrup, T.B., 2004. Urban Forestry. In: Encyclopedia of Forest Sciences (eds: Burley, J., Evans, J., Youngquist, J. A.) Elsevier, pp. 471-478.

Kuuluvainen, J., Karppinen, H., Hänninen, H., Uusivuori, J., 2014. Effects of gender and length of land tenure on timber supply in Finland. J. For. Econ. 20 (4), 363-379.

Madureira, H., Nunes, F., Oliveira, J.V., Cormier, L., Madureira, T., 2015. Urban residents' beliefs concerning green space benefits in four cities in France and Portugal. Urban Forestry \& Urban Greening, 14, 56-64.

Majumdar, S., Deng, J., Zhang, Y., Pierskalla, C., 2011. Using contingent valuation to estimate the willingness of tourists to pay for urban forests: A study in Savannah, Georgia. Urban Forestry \& Urban Greening, 10(4), 275-280.

Matilainen A., Koch M., Zivojinovic I., 2019. Perceptions of ownership among new forest owners - A qualitative study in European context. Forest Policy and Economics 99, 43-51.

Mell, lan C., 2017. Green infrastructure: reflections on past, present and future praxis. Editorial, Landscape Research, 42(2), 135-145. DOI: 10.1080/01426397.2016.1250875

Millennium Ecosystem Assessment (MEA), 2005. Ecosystems and human well-being: current state and trends. Island Press, Washington (DC).

Mikulić, J., Krešić, D., Prebežac, D., Miličević, K., Šerić, M., 2016. Identifying drivers of destination attractiveness in a competitive environment: A comparison of approaches. Journal of Destination Marketing \& Management, 5(2), 154-163. 
O’Brien L., De Vreese, R., Atmis, E. et al., 2017. Social and Environmental Justice: Diversity in Access to and Benefits from Urban Green Infrastructure - Examples from Europe. In: Pearlmutter D. et al. (eds) The Urban Forest. Future City, vol 7. Springer, Cham

Page, S., 1995. Urban Tourism. Routledge, London.

Parker, J. and Zingoni de Baro, M.E. (2019) Green Infrastructure in the Urban Environment: A Systematic Quantitative Review. Sustainability 2019, 11, 3182;

Payne, A., Storbacka, K., Frow, P., Knox, S., 2009. Co-creating brands: Diagnosing and designing the relationship experience. Journal of Business Research, 62 (3), 379-389.

Sasidharan, V., Willits F., Godbey G., 2005. Cultural differences in urban recreation patterns: An examination of park usage and activity participation across six population subgroups, Managing Leisure 10(1), 19-38, DOI: 10.1080/13606710500086710

Schipperijn, J., Ekholm, O., Stigsdotter, U.K., Toftager, M., Bentsen P., Kamper-Jørgensen, F., Randrup T.B., 2010. Factors influencing the use of green space: Results from a Danish national representative survey. Landscape and Urban Planning, 95, 130-137.

Selby, M., 2012. Geographies of tourism and the city. In: Wilson, G. (ed.) The Routledge Handbook of Tourism Geographies, Routledge, London, 232-239.

Simon, A., 2004. Successful urban forestry in the city centre - Is it all about image? In J. Schipperijn \& K. K. Hoyer (Eds.), Forestry serving urbanised societies: Selected papers from the conference held in Copenhagen, Denmark, from 27 to 30 August, 2004 (pp. 351-356). US: IUFRO Headquarters.

Shoval, N. 2018. Urban planning and tourism in European cities. Tourism Geographies 20(3), 371376.

Terkenli, T.S., 1996. The Cultural Landscape: Geographical Perspectives. Papazissis Publications, Athens (in Greek).

Terkenli T.S., Bell, S., Živojinović, I., Tomićević-Dubljević, J., Panagopoulos, T., Straupe, I., Toskovic, O., Kristianova, K., Straigyte, L., O’Brien, L., 2017. Recreational Use of Urban Green Infrastructure: The Tourist's Perspective. In: Pearlmutter D. et al. (eds) The Urban Forest. Future City, vol 7. Springer, Cham

Tomićević, J., 2005. Towards Participatory Management: Linking People, Resources and Management. A Socio-Economic Study of Tara National Park. Culterra, Schriftenreihe des Instituts für Landespflege der Albert-Ludwigs-Universität Freiburg, Heft 43, Freiburg. 
Tyrväinen, L., Pauleit, S., Seeland, K., de Vries, S., 2005. Benefits and Uses of Urban Forests and Trees. In: Konijnendijk C., Nilsson K., Randrup T., Schipperijn J. (eds) Urban Forests and Trees. Springer, Berlin, 81-114.

Tyrväinen, L., Gustavsson, R., Konijnendijk, C. Ode, A., 2006. Visualization and landscape laboratories in planning, design and management of urban woodlands. Forest Policy and Economics, 8, 811823.

Tyrväinen, L., Mäkinen, K., Schipperijn, J., 2007. Tools for mapping social values of urban woodlands and other green areas. Landscape Urban Plann. 79, 5-19.

UNWTO \& UNEP. 2011. Tourism: investing in the green economy. In: Towards a Green Economy, United Nations Environmental Programme, Geneva, 409-447.

UNWTO, 2011. Tourism Trends 2030: Global Overview. UNWTO General Assembly, $19^{\text {th }}$ Session, Gyeongju, Republic of Korea, 10 October 2011, UNWTO, Madrid.

Urry, J., 1995. Consuming Places. Routledge, London.

Vujcic, M., Tomicevic-Dubljevic, J., 2018. Urban forest benefits to the younger population: The case study of the city of Belgrade, Serbia. Forest Policy and Economics 96, 54-62.

Vujcic, M., Tomicevic-Dubljevic, J., Zivojinovic, I., Toskovic, O., 2019. Connection between urban green areas and visitors' physical and mental well- being. Urban Forestry \& Urban Greening 40, 299-307.

Wiltshier, P., 2009. A Review of "Religious" tourism and pilgrimage management. Journal of Sustainable Tourism, 17, 408-409.

Witt, S.F., 2014. Opening of the Eastern Bloc Countries to Inbound Tourism. Proceedings of the 1993 Academy of Marketing Science (AMS) Annual Conference, 677-677

WTO/ETC, 2005. City Tourism \& Culture - The European Experience, World Tourism Organization and European Travel Commission, ETC Research Report No 2005/1, World Tourism Organization, Madrid, Spain, 137. Available at: http://81.47.175.201/stodomingo/attachments/article/122/CityTourismCulture.pdf (assessed 10 November 2019)

Yuan, J., Deng, J., Pierskalla, C., King, B. 2018. Urban tourism attributes and overall satisfaction: An asymmetric imact-performance analysis. Urban Forestry and Urban Greening 30, 169-181.

Živojinović, I., Wolfslehner, B., 2015. Perceptions of urban forestry stakeholders about climate change adaptation - A Q-method application in Serbia. Urban For. Urban Green. 14, 1079-1087. 
Annexes

Annex 1. Groups of countries of origin with the list of countries that belong to them

\begin{tabular}{|l|l|}
\hline Northern Europe & United Kingdom, Estonia, Finland, Sweden, Ireland, Latvia, Lithuania, Norway \\
\hline Central Europe & $\begin{array}{l}\text { Austria, Germany, Belgium, Belarus, Hungary, Denmark, Czech, France, } \\
\text { Netherlands, Luxembourg, Poland, Slovakia, Slovenia, Switzerland, Ukraine }\end{array}$ \\
\hline Southern Europe & $\begin{array}{l}\text { Spain, Bosnia and Herzegovina, Bulgaria, Croatia, Cyprus, Greece, Italy, North } \\
\text { Macedonia, Montenegro, Portugal, Romania }\end{array}$ \\
\hline Non-European & $\begin{array}{l}\text { Armenia, Australia, Thailand, Brazil, Canada, United States of America, Chile, } \\
\text { China, Colombia, India, Israel, Japan' 'Korea, Malaysia, Mexico, Myanmar, New } \\
\text { Zealand, Nigeria, Panama, Turkey, Russia, Somalia, Taiwan, Uruguay, Argentina , } \\
\text { Bangladesh, Barbados, Cayman Islands, El Salvador, Ghana, Indonesia, Iran, } \\
\text { Jamaica, Pakistan, Peru, Sri Lanka }\end{array}$ \\
\hline
\end{tabular}

Annex 2. Cattell scree plots for performed factor analysis

Interest in UGI

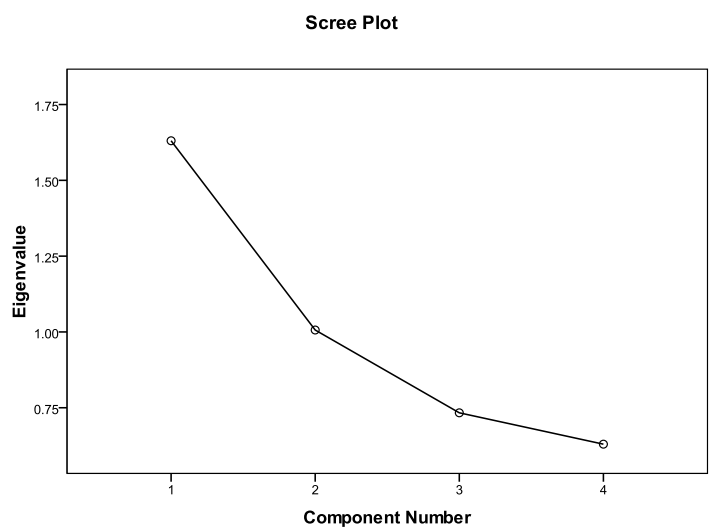

Willingness to pay for UGI

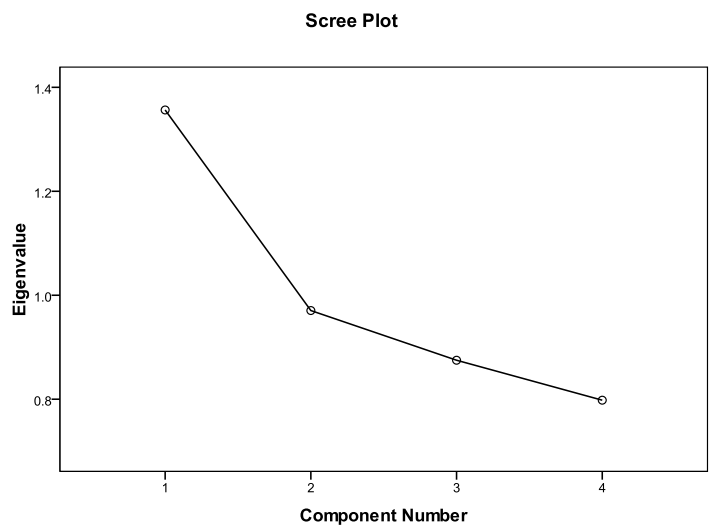

Intention using UGI

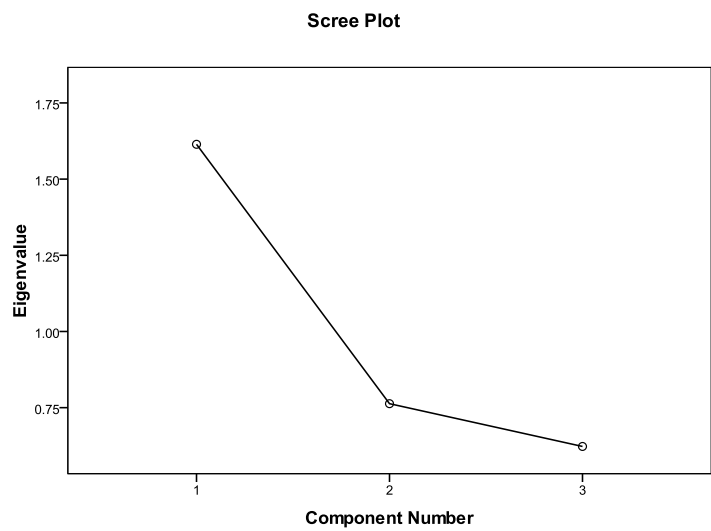

SES

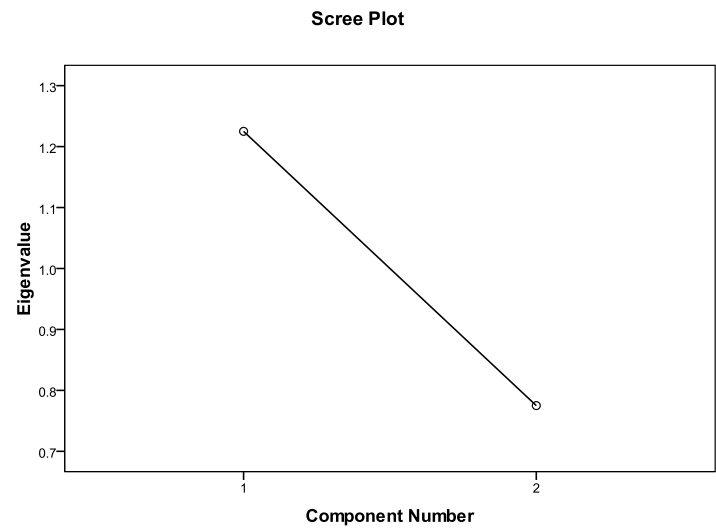

